\title{
THE MILLER ACT: ENFORCEMENT OF THE PAYMENT BOND
}

\author{
Robert D. Wallick* and John A. Stafford
}

I

Introduction and ScOpe of ARTTCLe

The Miller Act is the federal construction bond statute. It requires prime contractors on most ${ }^{2}$ federal construction contracts to furnish payment and performance bonds. The statute is short and concise, with most of its substantive provisions in a single section-27ob. Because of this, one might think it dull and unimportant, but nothing could be further from the truth. It is very much in the mainstream of federal construction legal practice.

It involves money, often a lot of money. It involves an industry famous for the size, frequency, and heat of its problems-and its failures. One need only look at the number and variety of the annotations behind the Miller Act to appreciate its importance and complexity.

No single article could adequately discuss all facets of the Miller Act. Actually, many of these are really surety law and not government contracting problems. Accordingly, in order to stay within the scope of the symposium, this article is limited to the problems of subcontractors and materialmen claiming under Miller Act payment bonds. Moreover, this is the primary area where the writers have had personal experience with the act.

\section{II}

\section{History and Purpose of the Miller Act}

The common law early recognized the need to protect persons furnishing materials and labor on construction projects by creating mechanics liens on commercial work; and these have been codified generally by our state legislatures into appropriate statutory liens. The doctrine of sovereign immunity, however, left the unpaid materialmen and subcontractors on federal construction work without similar protection. The finished project was, of course, immune from lien. ${ }^{3}$

* B.S. Elec. Eng., 1948, B.S. Bus. Admin., I949, Lehigh University; LL.B. 1955, Gcorge Washington University. Certified Public Accountant. Partner, Steptoe \& Johnson, Washington, D.C. Member of the District of Columbia and Maryland bar associations.

†A.B. 1959, Dickinson College; LL.B. I962, George Washington University. Associatc, Steptoe \& Johnson, Washington, D.C. Member of the District of Columbia bar.

149 Stat. 793 (I935), as amended, 40 U.S.C. $\$ 270 a-270$ (I958).

2 The act may be waived by contracting officers on foreign work. See $\$ 270(\mathrm{a})(\mathrm{b})$. The Secretaries of the Military Services may waive the act on work performed by their departments. See $\$ 270$ (c). The act does not limit the authority of contracting officers to require performance bonds or other security on contracts not covered by $\$ 270 \mathrm{a}$. The act applies only to contracts exceeding $\$ 2,000.00$ in amount. See $\$ 270 a(a)$.

${ }^{8}$ See United States v. Munsey Trust Co., 332 U.S. 234 (1947). And, of course, lack of privity with 
Congress first attempted to eliminate that inequity by passing the so-called Heard Act in $1894 .{ }^{4}$ That act established a single performance and payment bond which did afford some protection to the unpaid subcontractors and materialmen, ${ }^{5}$ but it was fraught with substantive and procedural limitations.

To correct these ${ }^{6}$ Congress passed the Miller Act in 1935, dividing the performance and payment features into separate bonds and changing the ground rules on procedures. $^{7}$ During the twenty-eight years since then, the patient has been on its own and apparently is doing fine. It does provide substantial protection to diligent subcontractors and materialmen, the purpose for which it was passed, and to that end, it has been given a very liberal construction by the courts in favor of such claimants. Thus, the United States Supreme Court, in an early case, stated: ${ }^{8}$

And we are committed to the doctrine that it should be liberally construed in aid of the public object-security to those who contribute labor or material for public works.

No one is entirely satisfied with the workings of the act as so interpretedsubcontractor, contractor, surety or the contracting agencies; but perhaps this is the best testimony possible on the balance it has struck among such conflicting interests.

\section{III}

\section{Contracts Covered by the Mrller Act}

The problems for claimants under the Miller Act payment bonds divide logically into these categories: what is covered; who is covered; and how to enforce coverage. We shall review them in that order.

The Miller Act is limited by its own terms to contracts “... for the construction, alteration or repair of any public building or public work of the United States. . ..",

The first question, then, is what constitutes a "public building or public work." The United States Supreme Court, in an early decision, United States to the Use of Noland Co. v. Irwin, ${ }^{10}$ addressed itself directly to that question and concluded that

the government prevents a direct suit against the government. Referring to the Heard Act, the court in United States to the Use of Salem-Bedford Stone Co. v. Sheridan, II9 Fed. 236, 239 (C.C. W.D. Ky. I902), stated: "The real purpose of the legislation was obviously to provide a guaranty of payment to laborers and materialmen through the medium of the bond required, inasmuch as they could not, without permission of the government, acquire any lien upon works of public improvement. ...." (See Note, Government Subcontractors' Remedies in Rem, 30 GEo. Wash. L. Rev. 994 (I962)).

*Aug. 13, I894, c. $280, \$ 1,28$ Stat. 278 .

" United States v. Churchyard, I32 Fed. 82, 85 (C.C. D. R.I. I904): "The penalty [under the bond] is defeasible upon two conditions: First, that the contractor shall do his work; second, that he shall pay his laborers and materialmen." Affirmed, United States Fidelity \& Guaranty Co. v. United States, Suing for the Benefit of James S. Kenyon, 204 U.S. 349 (1907).

'See Clifford E. MacEvoy Co. v. United States, 322 U.S. I02, I06-07 (I944).

${ }^{7}$ For a more complete discussion of the legislative story behind the Miller Act, see Stickells, Bonds of Contractors on Federal Public Works-The Miller Act, 36 Bost. L. REv. 499 (I956).

${ }^{8}$ Standard Accident Insurance Co. v. United States for the Use and Benefit of Powell, 302 U.S. 442, 444 (1938).

${ }_{40}$ U.S.C. $\$ 270 a(a)$ ( 1958 ). See supra note 2 , re discretionary waiver of the act's requirements on certain military and foreign contracts.

${ }^{10} 316$ U.S. 22 (1942). 
the term "public works" was to be interpreted broadly, holding that the act applied to a contract issued by the federal government, pursuant to its public works program, for construction of a library for Howard University, even though the university was a private institution.

The Court relied heavily upon the legislative history of the Miller Act, in which it was stated that the act would apply to the public works program being conducted under the National Recovery Act. The latter act had defined public works as including "any projects of the character heretofore constructed or carried on either directly by public authority or with public aid to serve the interests of the public."

The Supreme Court refused to apply a narrower definition of "public work" which had been developed by a lower court under the Heard Act in a case involving the same institution, Howard University:" "Whatever may have been the validity of this narrow formula when applied to the Heard Act, we cannot approve its application to this suit under the Miller Act."12

The Court noted that the concept of "public works" changed considerably since I897 and that title to the property "is no longer of primary significance."

The Court cited with approval a decision by the court of appeals for the sixth circuit, in Peterson v. United States for $U_{s e}$ of Marsh, ${ }^{13}$ under the old Heard Act. The prime contractor had there defended a claim under the payment bond on the grounds that the government did not own the buildings and land being worked on and that the project was therefore not a "public building or public works" within the purview of the Heard Act. But the circuit court had rejected this contention, holding that Congress did not use the term "public works" in its technical sense. The court noted that the job in question was part of the improvement of a navigable stream, and, therefore, was for the public good. The court stated that the act here in question includes (a) work done on property belonging to the United States, and (b) all fixed works constructed for the public use at the expense of the United States.

In a particular case, the question could arise as to whether the contract was one for "construction, alteration or repair"-just as it has over whether it involved a "public building or public works." Our research, however, has not uncovered such a case.

The broad interpretation given to the term "public work" by the Supreme Court in Noland is in keeping with the Court's liberal views on claims under the act generally. It also makes sense as a simple matter of fair play. The party who claims the Miller Act is inapplicable normally is the prime contractor or his surety. Both,

${ }^{11}$ Maiatico Construction Co. v. United States to the Use of Phelps, 79 F.2d 4 I 8 (D.C. Cir. I935).

12 United States to the Use of Noland Co. v. Irwin, 316 U.S. 22, 29 (1942).

1s 119 F.2d 145, I47 (6th Cir. 194I). The Court in Peterson distinguished the first of the two Howard University cases, Maiatico Construction Co. v. United States to the Use of Phelps, 79 F.2d $4 \mathrm{I} 8$ (D.C. Cir. I935), as inapplicable on the basis that the government had no interest in the property or the school was not tor public use. But, of course, in the Noland case, the Supreme Court did not attempt to distinguish the first Howard University case but merely denied its application to the Miller Act concept of public works. See 316 U.S. at 28-29. 
however, were willing parties to the original payment bond. Thus, in Noland the Supreme Court noted :14

The respondents evidently had no difficulty interpreting the language of the Recovery Act until they were called upon to meet the claims of petitioner. The record does not reveal that Irwin \& Leighton objected to posting the bond when the contract was executed. It paid a premium of $\$ 8,172.25$ for the bond and the surety company accepted it without question. Presumably, these are the circumstances which caused the Court of Appeals to remark upon "the strong equities" of petitioner's case.

Of course, hope springs eternal in mankind, particularly where large sums of money are involved. We can expect that prime contractors and their sureties will continue to test applicability of the act in original contract situations. Thus, recently a claim was unsuccessfully resisted with the argument that military projects were not "public works."15

\section{IV}

\section{Items Covered by the Miller Acr}

The payment guarantee under a Miller Act bond covers: ${ }^{16}$

Every person who has furnished labor or material in the prosecution of the work provided for in such contract in respect of which a payment bond is furnished under section 270 (a) of this title and who has not been paid in full therefor before the expiration of ninety days after the day on which the last of the labor was done or performed by him or material was funished or supplied by him for which such claim is made. ...

To paraphrase the essential parts of this provision, payment is guaranteed for (I) labor done or performed and (2) materials furnished or supplied, (3) in the prosecution of the work provided for in the contract. Much of the litigation has been in this area; and, as a result, the abstract meanings of the terms used are rather well defined-although, of course, there always will be the question of applying those definitions to particular cases. In keeping with the purposes of the act, the courts have adopted a broad view on what constitutes labor or materials. Thus, in an early case brought under the Heard Act, it was stated that: ${ }^{\mathbf{1 7}}$

while each case must be considered in the light of its own particular facts, it is generally held that anything that is indispensable to the work when contracted for falls within the meaning of the words labor and materials.

Marginal items which have been held to constitute "labor and materials," and which are therefore protected by Miller Act payment bonds, include the following:

is Supra note Io, at 30 .

${ }^{10}$ See United States, at the Relation of and for the Use of Westinghouse Electric Supply Co. v. National Surety Corp., I79 F. Supp. 598 (E.D. Pa. 1959). The court specifically followed the decision of the United States Supreme Court in Noland, supra note ro.

${ }^{10} 40$ U.S.C. $\$ 270 b$ ( 1958$)$. (Emphasis added.) For an excellent summary on items covered, see Annot., 79 A.L.R.2d 843-59 (I96r).

${ }^{17}$ United States to the Use of Watsabough Co. v. Seaboard Surety Co., 26 F. Supp. 68I (D. Mont. I938). 
I. Union fringe benefits. ${ }^{18}$

2. Transportation charges. ${ }^{19}$

3. Food. ${ }^{20}$

4. Gas and Oil. ${ }^{21}$

5. Equipment rentals.

6. Equipment repairs.

The last two items deserve particular comment. Generally, a lessor of equipment used in the prosecution of a job is entitled to recover for rentals ${ }^{22}$ under the bond, even though the equipment is not incorporated in the project. $^{23}$ Similarly, the supplier of repair parts needed to replace parts consumed in the prosecution of the work is protected by the bond. ${ }^{24}$

The problem, however, is whether a particular repair or rental item is a cost

${ }^{18}$ United States for Benefit and on Behalf of Sherman v. Carter, 353 U.S. 210 (1957). The Supreme Court held that a Miller Act payment bond affords coverage for payments owed by an employer under a collective bargaining agreement to a trust fund established to provide health and welfare benefits to construction employees, some of whom worked for the defaulting employer. The Court rejected the surety's arguments that the trustees of the fund, who brought the suit, were not persons "who had furnished labor or material" to the job, that they were not persons "not . . . paid in full," and that they were not persons with "sums justly due" them. The Court declined to decide that the trustees were "in a technical sense, assignees of the employees' rights to the contributions," but still relied heavily on precedents allowing payment bond suits by assignees. The Court thus held that such payments were obligations of the employer covered by the bond, and that the trustees were proper partics to enforce such claim.

${ }^{10}$ Standard Accident Insurance Co. v. United States for the Use and Benefit of Powell, 302 U.S. 442 (1938). The case involved a suit brought by a railroad under the Heard Act for frcight charges on materials brought to the job site. The Court held that transporting freight was "labor" and that the railroad had "furnished labor" used in the construction of a public building within the meaning of the act. The Court stated: "And we are committed to the doctrine that it should be liberally construed in aid of the public object-security to those who contribute labor or material for public works." See also United States for the Use and Benefit of Wyatt \& Kipper Engineer Inc. v. Ramstad Construction Co., I94 F. Supp. 379 (D. Alaska I96I); and also United States for the Use of Benkart Co. v. John A. Johnson \& Sons, Inc., $236 \mathrm{~F} .2 \mathrm{~d} 864$ (3d Cir. 5956 ). In the latter case, the court allowed a claim brought on a Miller Act payment bond, for dismantling, transporting and loading a steam shovel on freight cars.

${ }^{20}$ United States for the Use of J. A. Postell v. B. Perini \& Sons, 159 F. Supp. $9 \times 1$ (N.D. Fla. 1958); United States for the Use of Brogan v. National Surety Co., 246 U.S. 259 (1918).

${ }^{21}$ United States for the Use and Benefit of Eoff Electric Co. v. Mann, xg6 F. Supp. 185 (D. Orc. 196r); United States for the Use of Harrington v. Trioni, 97 F. Supp. 522 (D. Col. 195I).

${ }_{22}$ In United States for the Use of Llewellyn Machinery Corp. v. National Surcty Corp., 268 F.2d 6ro (5th Cir. 1959), cert. denied, 36r U.S. 914 (1959), the court of appeals went further than merely allowing recovery on the bond for rentals. It held that a payment bond covered the replacement value of rented machinery lost en route to the project where the lessee assumed responsibility of loss. A majority of the court reasoned that the assumption of risk of loss by the lessee was merely a part of the rental payment. See Note, 45 VA. L. REv. 1243 (I959), approving the majority opinion. The dissent, however, termed this reasoning a non sequitur, stating (id. at 6I2) that the majority's holding "converts the surety on a Miller Act bond into a general insurer up to the limits of its bond of all property, without limit as to its value, leased or loaned to the prime contractor when it is lost or destroyed by him with or without his fault."

${ }^{23}$ See United States for Use and Benefit of P. A. Bourquin \& Co. v. Chester Constr. Co., 104 F.2d 648 (2d Cir. 1939); Basich Bros. Construction Co. v. United States for Use of Turner, I59 F.2d 182 (9th Cir. I946); and Friebel and Hartman, Inc. v. United States for the Use of Codell Construction Co., 238 F.2d 394 (6th Cir. 1956).

24 See United States for the Use and Benefit of J. P. Byrne \& Co., Inc. v. Fire Assoc., 26o F.2d 54I (2d Cir. I958); and United States for the Use and Benefit of Wyatt \& Kipper Engincers, Inc. v. Ramstad Construction Co., I94 F. Supp. 379 (D. Ala. I961). 
of the job or a capital expenditure. They are not covered by the bond to the extent that they fall in the latter category, capital expenditures. Thus, the eighth circuit recently held that the defendant surety should be afforded the opportunity to show that some part of "rental payments" for heavy equipment constituted consideration for an option to purchase the equipment. ${ }^{25}$ To that extent they would be capital expenditures for permanent equipment and not recoverable in a suit on a payment bond. $^{26}$

As for determining whether repair and maintenance parts are capital expenditures, the test was summarized by one court recently as follows: ${ }^{27}$

... perhaps the most important factor in distinguishing materials from capital equipment has been substantial consumption. ... A more recent view, which we here adopt, focuses on the degree of expected consumption of the items on the particular job for which they were furnished.

Applying this rule, the court held that the cost of tires furnished for use on heavy earth-moving equipment, and which both the plaintiff and purchasing contractor expected to be substantially used up in the course of the work, was a recoverable item under the bond, whether, in fact, so consumed or not. The court, on the other hand, did not allow recovery for tires furnished for "pick-up" trucks which merely operated over the public highways and were not used to haul materials for the job.

On leased equipment, repair parts which are furnished to the lessor-contractor while the contract is in progress are clearly covered by the payment bond, if they merely replace parts consumed in the prosecution of the work. However, if the parts substantially increase the value of the machinery, rendering it available for other projects, the costs are not recoverable. ${ }^{28}$

There is a conflict of authority as to repairs done by the lessor itself after return of equipment. Some courts have permitted recovery by the lessor in such situations. ${ }^{29}$ Other courts, however, have held that "the surety may not be held liable for repairs made to equipment after completion of the work."30

The latter rule seems more reasonable. Repairs to equipment after completion of the job and return to the lessor would be for no other reason than to render the equipment available for use on other work. Applying the usual tests, the repairs

${ }^{25}$ Union Pacific Ins. Co. v. United States ex rel. Mississippi Valley Equipment Co., 296 F.2d I60 (8th Cir. I96r).

${ }^{20}$ Continental Casualty Co. v. Clarence, $x_{40}$ F.2d Ix5 (roth Cir. I944); United States for the Use and benefit of Miller \& Bentley Equipment Co., Inc. v. Kelley, I92 F. Supp. 274 (D. Ala. I96r).

${ }^{27}$ United States for the Use and Benefit of J. P. Byrne \& Co., Inc. v. Fire Assoc., supra note 24, at 544 .

${ }^{23}$ United States for the Use and Benefit of Wyatt \& Kipper Engineers, Inc. v. Ramstad Construction Co., supra note 24 .

${ }^{30}$ Continental Casualty Co. v. Clarence L. Boyd Co., I40 F.2d II5 (roth Cir. 1944). In the Wyatt $\&$ Kipper case, supra note 24 , the court held that a claim for repairs where the equipment was "returned to the plaintiff by the defendant in a damaged condition," was within the provisions of the act.

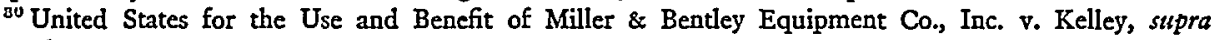
note 26 . 
would not have been consumed in the course of the work and would not be merely incidental and contemporaneous with the prosecution of the work. ${ }^{31}$

Thus, the terms "labor" and "materials," as used in the act, are broad and include almost everything consumed in the normal course of the project, whether or not they are, in fact, labor or material in the normal sense of those words. The more subtle question is whether they were "performed or furnished in the prosicution of the work provided for in the [prime] contract."

This would seem to mean merely that the subcontractor, in order to recover on his bond, must perform his work (a) in a workmanlike manner, (b) in accordance with his own contractual obligations, and (c) with the intent to thereby further the project bonded. Obviously, work which is defective through fault of the subcontractor or which does not comply with the specifications applicable to the subcontractor is not covered by the bond. ${ }^{32}$

The subcontractor, however, is not a guarantor of the specifications and may recover on the bond where defects are ones of design and not of construction..$^{33}$

The subcontractor may recover on the bond for work he was required to perform on the project by the prime contractor, even though it was not specified in the original plans and specifications for the prime contractor. This is true of extra work performed at the prime contractor's request to comply with a change ordered by the owner. ${ }^{34}$ It is also true for extra work ordered by the prime contractor, if in furtherance of the project, even though the work may be mere gold-plating, may not have been ordered by the owner, or otherwise may not be compensable under the prime contract. ${ }^{35}$ The fact that the prime contractor cannot receive extra compensation for the work does not affect the subcontractor's rights under his subcontract on the payment bond.

Establishment of a subcontractor's claim for labor or materials in an action brought under the Miller Act, is not dependent upon a showing that the labor or materials furnished were of benefit to the prime contractor. All that is required is proof that the labor or material was furnished in the prosecution of the work provided for in the prime contract, and that the subcontractor has not been paid therefor. ${ }^{36}$

It is not necessary that the items claimed by a subcontractor under the bond be covered by a written subcontract. In the absence of such an instrument, the sub-

${ }^{31}$ See Continental Casualty Co. v. Clarence L. Boyd Co., supra note 29.

${ }^{32}$ Sec United States for Use and Benefit of Lichter v. Hencke Construction Co., I57 F.2d I3 (8th Cir. 1946), where subcontractor could not recover extra costs attributable to requiring strict performance per basic specifications; Robinson v. United States, $25 \mathrm{I}$ Fed. $46 \mathrm{I}$ (2d Cir. 1918), error dismissed, 257 U.S. $66_{4}$ (I92I), where subcontractor could not recover for work rejected by owner.

${ }^{33}$ United States for Use of Ardmore Concrete Material Company v. Williams, 240 F.2d 561 (10th Cir. 1957).

3s See United States v. Fleischman Construction Co., 298 Fed. 320 (D. Va. 1923), affd, 298 Fed. 330 (4th Cir. 1924), aff'd, 270 U.S. 349 (1926).

${ }^{35}$ See Sam Macri \& Sons, Inc. v. United States for Use of Oaks Construction Co., 3r3 F.2d Irg (9th Cir. I963); United States for the Use and Benefit of Warren Painting Co., Ine. v. Boespflug Construction Co. et al., 325 F.2d 54 (9th Cir. I963).

${ }^{36}$ United States for Use and Benefit of Warren Painting Co., Inc. v. J. C. Bocsplug Construction Co., et al., 325 F.2d 54, 62 (9th Cir. 1963). 
contractor may recover, under the bond, for the reasonable value of labor and materials under the theory of quantum meruit. ${ }^{37}$ The subcontractor's price for such is not then limited or controlled by what might be agreed for the same item by the owner and the prime contractor, ${ }^{38}$ although obviously he is controlled by any written contractual commitments of his own. ${ }^{39}$

If the subcontractor does not breach his own subcontract, he may recover on the bond under the theory of quantum meruit for partial performance. ${ }^{40}$

As a general rule, it is not necessary for coverage that the materials or labor actually be used or expended directly on the project. ${ }^{41}$ It is sufficient that they be furnished with the intent that they be so used or expended.

We hold that in order to recover under the Miller Act, it is not required of the materialman that he prove that his materials were actually used in the prosecution of the work of the prime contract, but only that in good faith he reasonably believed the materials were so intended. ${ }^{42}$

If materials indispensable to the work are furnished to a subcontractor with the good faith expectation that they will be used in the prosecution of the work, the materialman will not be precluded from recovering on the bond merely because the subcontractor diverts the material to another job or to his own use. ${ }^{43}$ In fact, the materials do not necessarily even have to be delivered to the job site if the requisite intent is there. ${ }^{44}$

An interesting fact situation arose in United States for the Use and Benefit of National US. Radiator Corp. v. D. C. Loveys Co.45 There the court held that even though materials were damaged in transit and therefore did not meet the

${ }^{37}$ Sam Macri \& Sons, Inc. v. United States for Use of Oaks Construction Co., 313 F.2d II9 (9th Cir. r963); Wunderlich Construction Co. v. United States ex rel. Reischel \& Cottrell, 240 F.2d $20 \mathrm{r}$ (roth Cir. 1957), cert. denied, 353 U.S. 950 (1957).

${ }^{38}$ United States for Use of Soda v. Montgomery, 253 F.2d 509 (3d Cir. 1958).

${ }^{30}$ United States for Use and Benefit of Larkin v. Platt Corporation, 306 F.2d 724 (Ist Cir. 1962), cert. denied, 371 U.S. 924 ( 1962 ).

${ }^{10}$ Sec Premier Roof Co. v. United States for Use and Benefit of Alpaca Electric Corp., 3×5 F.2d 18 (9th Cir. 1963); Narragansett Imp. Co. v. United States for Use and Benefit of Mello, 290 F.2d 577 (Ist Cir. I96r).

${ }^{11}$ Brogran v. National Surety Co., 246 U.S. 257 (1918); United States for the Use and Benefit of Miller \& Bentley Equipment Co., Inc. v. Kelley, 192 F. Supp. 274 (D. Ala. 196r); for a contrary interpretation of the Heard Act, see United States ex rel. Purity Paint Products Corp. v. Aetna Casualty \& Surety Co., 56 F. Supp. 43I (D. Conn. I944).

42 United States v. Endebrock-White Company, 275 F.2d 57, 60 (4th Cir. I960); Fourt v. United States, 235 F.2d 433 (Ioth Cir. 1956); and Annot., 79 A.L.R.2d 850-52 (I961).

${ }^{13}$ Glassell-Taylor Co. v. Magnolia Petroleum Co., I53 F.2d 527, 530-31 (5th Cir. 1946): "There is no provision in the statute requiring that materialmen must deliver the materials at the job site or that the materials be 'used' in the prosecution of the work. The statute only requires that the materials be 'furnished' in the prosecution of the work." Thus, the court allowed recovery for the gas and oil even though some of it was not used on the job but was diverted to private use. The court put the burden of checking on the subcontractors on the prime contractor. The court noted: "After all, the prime contractor selects his own subcontractors and it seems not unjustly harsh that he should be holden for their laxities." See also Commercial Standard Ins. Co. v. United States for Use of Crane Co., 213 F.2d 106 (Ioth Cir. 1954).

"Montgomery v. Unity Electric Co., I55 F. Supp. I79 (D. Puerto Rico I957).

${ }^{2}{ }_{74}$ F. Supp. 44 (D. Mass. 1959), aff'd, 275 F.2d 372 (Ist Cir. 1960). 
specifications when received by the subcontractor, the surety was liable because the risk of loss in transit had been assumed by the purchasing subcontractor.

\section{Persons Covered by the Mrller Act Payment Bond}

There is language in the Miller Act which would indicate that any "person" furnishing labor or materials to a project could be covered by the payment bond. ${ }^{40}$ However, section $270 \mathrm{~b}$ of the act provides

... that any person having a direct relationship with a subcontractor but no contractual relationship express or implied with the contractor furnishing said payment bond shall have a right of action upon the said payment bond upon giving written notice to said contractor. ...

In a landmark decision, Clifford E. MacEvoy v. United States, ${ }^{47}$ the United States Supreme Court interpreted the language in section $270 \mathrm{~b}$ as precluding recovery under the bond by a second tier supplier-that is, by a supplier of a materialman for the prime contractor. There was no direct relationship between the supplier and the prime contractor in that case. The Court relied upon the rule of statutory construction that specific language prevails over general, and concluded that section $27 \mathrm{ob}^{48}$

makes clear that the right to bring suit on a payment bond is limited to (I) those materialmen, laborers and subcontractors who deal directly with the prime contractor and (2) those materialmen, laborers and subcontractors who, lacking express or implied contractual relationship with the prime contractor, have direct contractual relationship with a subcontractor. ...

The decision was reached, despite express recognition by the Court, that the act "is highly remedial in nature" and "entitled to a liberal construction ... to protect those whose labor and materials go into public projects," and despite the broad language elsewhere in the act, indicating it applies to "all persons." The Court noted, as a policy consideration, that a contrary holding would extend the prime contractor's liability to "remote and undeterminable" persons. ${ }^{40}$

The rationale of the Supreme Court in MacEvoy has been extended by the fifth circuit to preclude recovery for "labor" as well as for "materials," furnished by persons

s6 40 U.S.C. $\$ 270 a(2)$ states that the payment bond is for "the protection of all persons supplying labor and material in the prosecution of the work. . ." $\$ 270 \mathrm{~b}$, in turn, gives a cause of action on the bond to "every person who has furnished labor or material in the prosecution of the work. ...."

${ }^{17} 322$ U.S. I02 (1944). The Court noted that it had not decided the question under the Heard Act. Id. at 105.

${ }^{8}$ Id. at 107.

10 The Court also noted that to allow the protection of the bond to extend to more remote relationships "would lead to the absurd result of requiring notice from persons in direct contractual relationship with a subcontractor but not from more remote claimants." Id. at ro8. 
having no direct contractual relationship with either the prime contractor or a subcontractor. ${ }^{50}$

The determination in this day and age of who is a "subcontractor" and who is a mere "materialman" for purposes of coverage of second and third tier parties under the bond is a difficult question. A company furnishing steel as materials often performs more complex and difficult labor than the subcontractor erecting it. This question has resulted in what appears to be a clear conflict of authority on the definition. Thus, the ninth circuit has held that a person furnishing gravel was a subcontractor through whom parties could claim $^{51}$ whereas the fifth circuit has held that a similar sand and gravel concern was not a subcontractor. ${ }^{52}$

In concluding that the gravel company was a subcontractor, the ninth circuit $^{53}$ relied on a general definition appearing in the Supreme Court's decision in MacEvoy: $: 44$

... under the more technical meaning as established by usage in the building trades a subcontractor is one who performs for and takes from the prime contractor a specific part of the labor or material requirements of the original contract, thus excluding ordinary laborers and materialmen.

The district court for the western district of Pennsylvania relied on the same language to conclude that a millwork supplier was a subcontractor. ${ }^{\mathbf{5 5}}$

The fifth circuit gave no explanation for its more recent conclusion that a sand and gravel concern was not a "subcontractor" and merely affirmed an unreported district court decision. However, the district court for Maryland, in a well reasoned and recent opinion, similarly concluded that a supplier of concrete cribbing was not a subcontractor, relying heavily on what is, in fact, the customary construction in the trade. ${ }^{58}$ Two important factors in that decision were:

I. Method of payment:

In the usage of the business there is a marked difference between a subcontractor and a material supplier with respect to payments by the prime contractor. ... [I]t is usual and customary to make payments to the prime contractor on the basis of an estimate. . . . as to the percentage of the whole work that has been satisfactorily performed; and where the prime contractor deals with a subcontractor similar proportionate payments are made. . .

${ }^{00}$ Elmer, d.b.a. Mississippi Testing Laboratories v. United States Fidelity \& Guaranty Co., 275 F.2d 89 (5th Cir. 1960); Annot., 79 A.L.R.2d 852 (rg6r).

${ }^{61}$ Basich Brothers Construction Co. v. United States for Use of Turner, I59 F.2d I82 (9th Cir. 1946).

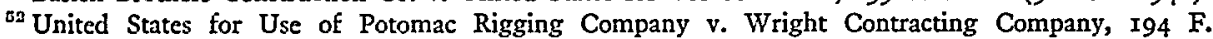
Supp. 444 (D. Md. 196I). The fifth circuit attempted to distinguish Basich on the facts, but the distinctions are at best tenuous. Id. at 450 .

${ }^{53}$ Basich Bros. Construction Co. v. United States for Use of Turner, supra note 5I, at 184 .

¿t Clifford E. MacEvoy Co. v. United States for Use and Benefit of Tomkins Co., 322 U.S. I02, I09 (I944).

${ }^{\circ}$ United States to the Use of Hardwood Products Corporation v. John Johnson, I37 F. Supp. 562,564 (W.D. Pa. 1955).

${ }^{00}$ United States for Use of Potomac Rigging Company v. Wright Contracting Company, I94 F. Supp. 444 (D. Md. I96r). 
Very generally ten percent of the whole contract or subcontract price is retained.... But in the case of a materialman, there is no such protection. . . ..$^{37}$

2. The fact that the prefabricated concrete supplier was not obliged to comply with contract requirements, for (a) advance approval by owner of all subcontractors, and (b) the furnishing of all subcontractor payrolls. ${ }^{58}$

The law is also unclear as to the status of one claiming through a second tier subcontractor, or a so-called sub-subcontractor. It apparently is possible that the scope of the sub-subcontractor's activities are so great that he will be treated as a subcontractor of the prime contractor, or at least so reasoned the district court for the middle district of Pennsylvania in holding that even a third tier, or subcontractor of a subcontractor, had standing as a subcontractor in his own right under the Miller Act: 59

.. Plaintiff [a third tier subcontractor who erected bunkers and posts] certainly qualifies under the wording of the MacEvoy case as one of the relatively fcw subcontractors who perform part of the original contract, and who accordingly represent in a sense the prime contractor and are well known to him.

On the other hand, the United States district court for Maryland has more recently reached an entirely different result and denied recovery under the bond to a third tier subcontractor, a so-called sub-sub-subcontractor. ${ }^{00}$ It is possible, but very difficult, to reconcile the two viewpoints on the basis of the relative amounts of direct participation in the work by the two different third tier subcontractors involved.

Does a subcontractor or materialman have a remedy if no bond is required on a contract falling within the scope of the Miller Act? Apparently he does not, ${ }^{01}$ although it seems he does have standing to insist upon a bond coextensive with the obligations created by the act, if there is a bond issued. ${ }^{62}$

On several occasions defendants have contended that use plaintiffs had no right to sue on the payment bonds because the plaintiffs were mere assignees of the persons who actually did the work or supplied the materials. But the courts have consistently rejected this defense, relying on Supreme Court cases under the Heard Act plus the general rule that an assignment of a debt carries with it the security. ${ }^{03}$

${ }^{57}$ Id. at 447 .

${ }^{58}$ Ibid.

${ }^{50}$ McGregor Architectural Iron Co. v. Merritt-Chapman \& Scott Corp., I 5o F. Supp. 323, 326 (D. Pa. 1957). Sec also United States for Use of West Pacific Sales Co. v. Harder Industrial Contractors, Inc., 255 F. Supp. 699 (D. Oregon 1963), where the court and AEC treated the prime contractor on an integrated procurement as mere supervising agent, with the construction subcontractor treated as a prime on his work; and Southern Industries, Inc. v. United States for the Use of James Bond Trucking Co., 326 F.2d 22 ( 9 th Cir. 1964), where corporate plaintiff was permitted to sue in its own right as an undisclosed principal.

"urited States for the Use of Newport News Shipbuilding and Drydock Co. v. Blount Bros. Construction Co., 168 F. Supp. 407 (D. Md. 1958).

${ }^{61}$ See United States v. Robert Smith d/b/a Smith Contracting Co. et al, 324 F.2d 622 (5th Cir. I963), in which the court held there was no liability under the Federal Tort Claims Act for failure to require a bond.

"United States for the Benefit and on Behalf of Sherman v. Carter, 353 U.S. $210,215-16$ (1957).

${ }^{63}$ United States for the Use and Benefit of Wolther v. New Hampshire Fire Insurance Co., x73 F. Supp. 
The right of an assignor of a claim under the Miller Act is enforceable even where the assignment is equitable. In a district court case ${ }^{64}$ it was held that a creditor of the prime contractor was entitled to recover from the bonding company amounts paid to employees of the prime contractor. The court stated: ${ }^{65}$

Apart from any question of [an agreement with the employee's representative] to obtain assignments, I am of the opinion that [the plaintiff's] claim could be properly allowed on principles of subrogation.

Of course, an assignee of a subcontractor does not acquire any rights against the surety in addition to those held by the assignor. Where suppliers of the subcontractor have asserted timely and valid claims against the surety, such claims must be paid before the assignee is entitled to any of the funds available under the bond for payment to the subcontractor. ${ }^{86}$

Ordinarily, creditors of a contractor are not protected by a Miller Act payment bond even where the money lent has been applied to the payment of the cost of labor and materials used on the construction project. ${ }^{67}$

VI

\section{Preservation and Enforcement of Rights Under Miller Act PAYMent Bonds}

As in all bonding and statutory lien situations, the law protects only those creditors who act diligently to perfect their rights. Notice and suit requirements in the Miller Act must be complied with strictly. The statute provides that a claimant must have been unpaid for ninety days after the day on which the last of the labor was done or performed by him or material was furnished or supplied by him. Technically, it would appear suit could not be brought before the end of such ninety-day period, although this apparently can be corrected by supplemental pleadings. ${ }^{68}$

\section{A. One Year Limitation on Suits}

Prior to 1959 , the act provided that suit had to be brought within one year after the "date of final settlement of such contracts" as certified by the Comptroller

529 (E.D.N.Y. I959); and Clifford E. MacEvoy Co. v. United States, supra note 54. See also United States for the Benefit and on Behalf of Sherman v. Carter, supra note 18, where a defendant sought summary judgment contending that the plaintiff assignor, who had furnished the labor and materials, was not the real party in interest under Rule $I_{7}(a)$ of the Federal Rules of Civil Procedure. The Court looked to state law and held that the assignor retained a substantive right to enforce the claim and was a proper party plaintiff.

of Continental Casualty Co. v. Haenn Ship Ceiling \& Refitting Corp., 134 F. Supp. 602 (E.D. Pa. 1955).

${ }^{85}$ Id. at 605 .

${ }^{10}$ Houston Fire \& Casualty Ins. Co. v. United States by and for the Use of the First State Bank of Denton, 217 F.2d 734 (5th Cir. 1954); 6 AM. Jur.2D Assignments, $\$$ I02 (1963).

${ }^{\circ 7}$ Bill Curphy Co. v. Elliot, 207 F.2d I03 (5th Cir. I953); United States for the Use of Dorfman v. Standard Surety \& Cas. Co., 37 F. Supp. 323 (S.D.N.Y. 194I). This is also the law generally, even where the Miller Act is not involved. See cases collected at Annot., 127 A.L.R. 974 (1940).

${ }^{08} 49$ Stat. 794 (1935), 40 U.S.C. $\$ 270 b$ (I958). See United States for the Use of C. W. Atkins v. Reiten \& Stewart Construction Co., 313 F.2d 673 (9th Cir. x963); see also Harry F. Ortlip Co. of Pennsylvania v. Alvey Ferguson Co., 223 F. Supp. 893 (E.D. Pa. 1963). 
General. However, at the request of the Comptroller General, Congress amended the act to its present form which requires that "no such suit shall be commenced after the expiration of one year after the day on which the last of the labor was performed or material was supplied by him." ${ }^{\circ 9}$

Suit must be brought within the one-year period, or rights under the bond lapse. ${ }^{70}$ In an industry known for its punch lists and corrective work, there can and will be disputes as to when the last of the work was performed or furnished for purposes of the one-year rule. Since the same determination is required under the ninety-day notice requirement which has been in the statute since its enactment, we shall examine the problem here.

\section{B. Ninety-day Notice to Prime Contractor}

Section $270 \mathrm{~b}$ (a) provides that a right of action on the payment bond is available to persons having a direct contractual relationship with a subcontractor, but no such relationship with the prime contractor, only

upon giving written notice to said contractor within ninety days from the date on which such person did or performed the last of the labor or furnished or supplied the last of the material for which such claim is made....

As in the case of a failure to bring suit within one year, failure to give notice when and if due is fatal to a cause of action. ${ }^{71}$

Where a materialman supplies materials on several occasions to a specific job, a question may arise whether the materials were supplied pursuant to (a) several separate orders, (b) a running open account, or (c) to a continuing contract. In the case of United States v. Peter Reiss Construction Company, ${ }^{72}$ the court held that where a supplier of a subcontractor received several separate purchase orders for electrical supplies, they were to be treated separately. The supplier could not revive a claim on which the ninety days had run by giving notice to the prime contractor regarding supplies on which the ninety days had not run. The court stated: ${ }^{73}$

${ }^{\circ 0}$ P.L. 86-r35, Aug. 4, 1959. See S. REP. No. 55r, 86th Cong., Ist Sess. 2 (1959), where it was stated: "The proposed change in the law should result in material savings to the Government when the expenses of the Comptroller General and those agencies having charge of the contracts are taken into consideration. . . . it will also provide for those entitled to sue under payment bond requirements of the Miller Act a simple, fixed, and certain method for determining the period within which the suit must be filed."

${ }^{70}$ See United States v. Seaboard Surety Co., 201 F. Supp. 630 (N.D. Tex. 196r); Fleisher Engincering \& Construction Co. v. United States, for the Use and Benefit of Geo. S. Hallenbeck, 3 II U.S. 15, 19 (1940) (suit within one year period is a "condition precedent to the right to sue"); United States for Use of M. A. Hartnett, Inc. v. Enterprise Enginecring and Construction Co., Inc., I69 F. Supp. I3I (D. Del. 1958) (one-year limitation period cannot be waived); United States for the Use of Weithman v. Buckley Union Casualty Co., 207 F. Supp. 552 (N.D. Ohio 1962).

${ }^{71}$ Fleisher Engineering \& Construction Co. v. United States, supra note jo; Cooley v. Barten \& Wood, Inc., 249 F.2d 9 I2 (rst Cir. I957). In merely deciding which days to count and which days to throw out, the courts have applied Rule 6 of the Federal Rules of Civil Procedure and do not count the last day work is done. See United States to the Use of Engineering and Equipment Co., Inc. v. W. B. Wyatt, I74 F. Supp. 260 (N.D. Fla. I959); United States for the Use and Benefit of Pre-Fab Erectors, Inc. v. A.B.C. Roofing \& Siding, Inc., 193 F. Supp. 465 (S.D. Cal. 196r).

${ }_{72} 273$ F.2d 880 (2d Cir. 1959), cert. denied, 362 U.S. 95 I (r960).

${ }^{73} \mathrm{Id}$. at $88 \mathrm{I}$. 
... it would be wholly inconsistent with the purpose of the notice provision of the Miller Act ... to hold that a shipment made on March 5, I957, under an order of February 20, 1957, could revive a Miller Act liability long extinguished and thereby place in jeopardy payments properly made by the contractor to the subcontractor in the interval.

In Noland Co., Inc. v. Allied Contractors, Inc., ${ }^{74}$ a supplier had two contracts (overlapping in time) with a subcontractor, with a single notice given to the prime contractor within ninety days after the last delivery under each contract. The fourth circuit held that the bond covered all materials delivered and not merely materials delivered ninety days (or less) prior to notice. The court stated the main purpose of the act as follows: $:^{75}$

It is true that the notice provision of the Miller Act is designed to afford protection to the prime contractor by fixing the date beyond which, in the absence of notice, he will not be liable for the subcontractor's debts; but this purpose, although important in itself, is subsidiary to the main purpose of the act to protect those whose labor and materials enter into the prosecution of the work; and if there be ambiguity in the provisions relating to the minor purpose, it should be resolved in support of the main object of the law. We believe this construction to be in harmony with the repeated decisions that hold that the statute should be liberally construed so as to effect its salutary purpose.

The Court in Peter Reiss noted the district court's opinion in Noland, to the effect that notice would not relate back over a whole chain of separate orders on an open account even though they were less than ninety days apart. The appeal to the fourth circuit, of course, reversed that ruling. ${ }^{76}$

Although the Peter Reiss and Noland cases can be distinguished on their facts it certainly is advisable for a supplier who receives several separate orders to give notice within ninety days after the last delivery under each order. This, of course, would avoid the legal difficulty of later determining whether he is dealing on an individual contract basis or an open account basis with occasional orders.

As to when the time starts to toll, it has been held that materials are not "furnished or supplied" until they reach the hands of the subcontractor, ${ }^{77}$ and where a sub-subcontractor left materials on the job and the subcontractor's employee incorporated the materials into the building some time later with the labor being charged back to the sub-subcontractor, the court held that notice given within ninety days after the work was done was sufficient. ${ }^{78}$ Nor did a change in the corporate entity of a subcontractor prevent a supplier's notice to the prime contractor from being good where notice was more than ninety days after corporate change but less than ninety days after furnishing of last materials to site. The court noted that the

" 273 F.2d $9 \times 7$ (4th Cir. I959).

${ }^{75}$ For a more narrow view of the statute, see United States for Use of Bruce Co., Inc. v. Fraser Constr. Co., Inc., 87 F. Supp. I (W.D. Ark. 1949).

${ }^{70}$ Sec also United States for the Use and Benefit of J. A. Edwards \& Co., Inc. v. Bregman Construction Corp., 172 F. Supp. 517 (E.D.N.Y. 1959).

${ }^{77}$ United States for the Use and Benefit of Westinghouse Electric Supply Co., Inc. v. EndebrockWhite Co., Inc., 275 F.2d 57 (4th Cir. 1960).

${ }^{78}$ United States for the Use of P. A. Bourquin \& Co., Inc. v. Chester Constr. Co., supra note 5I. 
second subcontractor corporation was related to and had interlocking officers with the first subcontractor corporation. ${ }^{79}$

Apparently a mere return for corrective work does not extend or renew the statutory ninety-day period. In United States for the Use of John T. Evanci \& Co. $v$. Merritt-Chapman \& Scott Corp. ${ }^{80}$ the court held that replacement of missing and defective parts several months after the final work was completed on the general contract would not extend the ninety-day period. The court noted that if repairs or replacement of defective parts could extend the ninety-day period, it would be difficult to know when the notice time actually ended. ${ }^{81}$

\section{Content of Notice}

Section $270 \mathrm{~b}$ provides that the notice to the prime contractor shall state "with substantial accuracy the amount claimed and the name of the party to whom the material was furnished or supplied or for whom the labor was done or performed."

It is well settled that the notice must be an affirmative claim directed to the prime contractor requesting payment of the sums due. ${ }^{82}$ Thus, in United States for the Use of J. A. Edwards \& Co. v. Thompson Construction Corp., ${ }^{83}$ the court held that the notice, ${ }^{84}$

must show it "was intended to be the presentation of a claim," a claim against contractor and its surety by the laborer or materialman in the latter's own right ... [and] it must state "with substantial accuracy" the amount claimed to be owing the laborer or materialman on the project and the name of the party to whom the material was furnished or supplied or for whom the labor was done or performed.

The notice in this case was merely a request by the subcontractor for consent of the prime contractor to an assignment to the materialman (plaintiff) of monies due to the subcontractor. The court stated $:^{85}$

... nothing on its [the letter's] face gave Thompson [the prime contractor] any reason to think that a direct claim against Thompson and the surety was being asserted [by the materialman for materials supplied to the subcontractor]. Yet such a "representation of a claim" is what the Act requires.

It has also been held that a letter from the subcontractor to the prime contractor listing the plaintiff's claim for materials supplied to the subcontractor and a letter from the subcontractor to the plaintiff referring to the first letter did not constitute adequate notice from the plaintiff to the prime contractor as required by the act.

\footnotetext{
${ }^{79}$ Apache Powder Co. v. Ashton Co., Inc., 264 F.2d 417 (9th Cir. 1959),

${ }^{80}{ }^{8}{ }_{5}$ F. Supp. 587 (M.D. Pa. 1960).

${ }^{81} \mathrm{Sec}$ also United States for the Use of McGregor Architectural Iron Co. v. Merritt-Chapman \& Scott Corp., 185 F. Supp. 381 (D. Pa. 1960).

${ }_{82}$ Actually, in view of the litigation on this particular point, perhaps Congress should have required the "presentation of a written claim" rather than the "giving of written notice."

${ }^{83}{ }_{273}$ F.2d 873, 874 (2d Cir. 1959), cert. denied, 362 U.S. 951 (1960).

st Id. at 876 .

${ }^{85} I d$. at $876-77$.
} 
The court noted that "the provisions of the act require a minimum attention and effort." 86

But where the notice is presented directly to the prime contractor by the claimant, the notice does not have to comply with the specific requirements of section $270 \mathrm{~b}$ (a) if the prime contractor is made aware of the nature of the claim. Thus, in the case of Houston Fire and Casualty Insurance Co.v. United States for the Use and Benefit of Trane Co., ${ }^{87}$ the supplier made an oral claim to the prime contractor for monies due to the supplier from a subcontractor. The prime contractor acknowledged the claim by letter to the supplier. The court held: ${ }^{88}$

It is not necessary that the writing relied on be signed by the supplier; it is sufficient that there exists a writing from which, in connection with oral testimony, it plainly appears that the nature and state of the indebtedness was brought home to the general contractor.

And, in the early landmark case of Fleisher Engineering \& Construction Co. $v$. United States, ${ }^{80}$ the Supreme Court set the tone for deciding issues of sufficiency of notice by stating: $:^{00}$

In giving the statute a reasonable construction in order to effect its remedial purpose, we think that a distinction should be drawn between the provision explicitly stating the condition precedent to the right to sue and the provision as to the manner of serving notice.

The Court held that actual receipt of the notice was the crucial point and the method of sending it was merely inserted in the act to assure receipt. Thus, notice sent by ordinary mail, when actually received, was sufficient compliance with the act, despite the stated requirement of registered mail. ${ }^{91}$

\section{Jurisdiction for Miller Act Suits}

Section $270 b(b)$ provides that payment bond suits shall be brought . . . in the United States District Court for any district in which the contract was to be performed and executed and not elsewhere, irrespective of the amount in controversy in such suit. ...

This language has been called "unequivocal" in its grant of "exclusive jurisdiction over suits on Miller Act bonds in the federal courts. . . ."92

But where the work in question is performed in a place where there are no federal courts, so much of section $27 \mathrm{ob}(\mathrm{b})$ which confines the suit to the district in which the work is done is inapplicable. Thus, where work is done abroad, a suit on a Miller Act payment bond may be brought in any federal court under 28 U.S.C.

so United States for the Use of Old Dominion Iron \& Steel Corp. v. Massachusetts Bonding and Insurance Co., 272 F.2d 73, 75 (3d Cir. I959).

${ }^{87} 217$ F.2d 727 (5th Cir. 1954).

${ }^{88}$ Id. at 730 .

${ }^{80}$ Supra note 70.

${ }^{\circ 0} 3$ II U.S. at I9.

01 Ibid.

${ }^{0 s}$ United States for the Use and Benefit of Bryant Electric Co., Ltd. v. Aetna Casualty \& Surety Co., 297 F.2d 665, 667 (2d Cir. I962). 
$\S$ I352, which grants jurisdiction to the district courts over all suits on bonds executed pursuant to a United States law. ${ }^{93}$

Although the courts are reluctant to enforce a claimants' waiver of his Miller Act rights, ${ }^{94}$ it has been indicated that where the intention to waive is certain, the claimant may bind himself to a determination of his claim before an administrative forum. ${ }^{95}$ And, in Electronics \& Missile Facilities, Inc. v. United States ex rel. Moseley, ${ }^{96}$ the court held that the Miller Act does not preclude enforcement of arbitration provisions under the United States Arbitration Act. ${ }^{97}$ There are various policy reasons which cast doubt on the soundness of this decision. In addition to the intention of Congress to protect laborers and materialmen, which militates against requiring submission to unwanted arbitration, there is the clear intention of allowing such claimants to litigate their claims in separate suits and in a court in the district where the project is constructed. Both of these intentions can be thwarted by arbitration provisions, inserted in subcontracts by the large prime contractors (perhaps at the urging of sureties) requiring arbitration of all claims in one proceeding, which may, by the terms of the contract, be distant from the place where the work is performed.

\section{VII}

\section{ConcLusion}

The payment bond under the Miller Act can provide important protection to materialmen, subcontractors, and laborers on federal construction projects. If they intend to rely on that bond for credit purposes, however, they should do the following:

(I) At the time the work is performed, clearly identify on invoices and other documents the government project involved.

(2) If they are not dealing directly with the prime contractor, be certain they are dealing directly with a first tier subcontractor, and not a second tier subcontractor or materialman.

(3) If they are not dealing directly with the prime contractor, place him on clear notice of any unpaid balance on each purchase order within ninety days after work under that purchase order is complete.

(4) Bring suit within one year after the work under the earlier purchase order is complete.

As for the prime contractor, we can only urge what they already know. They must watch their subcontractors carefully. They should not disburse to them unless they are certain the subcontractors' payrolls, suppliers, and lower tier subcontractors are all fully satisfied.

\footnotetext{
${ }^{83}$ Ibid.

'4 Cushman, Surety Bonds on Federal Construction Contracts, 25 Ford. L. Rev. $24 \mathrm{I}$ (1956).

${ }^{95}$ Fanderlik-Locke Co. v. United States for the Use of Morgan, 285 F.2d 939 (roth Cir. I960). (This case mentions a possible situation in which the doctrine of exhaustion of administrative remedies is reversed, with the administrative machinery being stayed pending a court decision.)

${ }_{90} 306$ F.2d 554 (5th Cir. 1962), rey'd on other grounds, 374 U.S. 167 (1963).

${ }^{97} 6$ I Stat. 670 (x947), 9 U.S.C. $\$ 2$ (I958).
} 